ORL 1980;42:I-IV

\title{
Contents, Vol. 42, 1980
}

\section{Contents Vol. 42, 1980}

No. $1-2$

Original Paper

Some Remarks on Ménière's Disease

Jongkees, L.B.W 1

Mechanism of the Ménière Attack

Dohlman, G.F 10

Ménière's Disease. With Special Emphasis on Epidemiology, Diagnosis and Prognosis

Watanabe, 120

Apical Lesions of the Cochlea in Idiopathic Endolymphatic Hydrops and other Disorders:

Pathophysiological Implications

Schuknecht, H.F. and Richter, E 46

Audiological Considerations in Ménière's Disease

Hood, J.D 77

Ménière's Disease

Mangabeira-Albernaz, P.L.; Fukuda, Y., and Malavasi-Ganança, M

Ménière's Disease: Results of Treatment with the Endolymphatic Subarachnoid Shunt

Brackmann, D.E. and Anderson, R.G101

Book Review 119

Announcements 120

No. 3

Original Paper

Interaction of Vestibular and Optokinetic Nystagmus in Patients with Peripheral Vestibular and Central Nervous Disorders

Böhmer, A. and Pfaltz, C.R 125

Fixation Frame for Electronystagmography in the Rat

Fischer, A.J.E.M.; Kuijpers, W., and Huygen, P.L.M

Contents

$\mathrm{HI}$

Simultaneous Primary Oat Cell Carcinoma (Apudoma) and Squamous Cell Carcinoma of the Hypopharynx

Ferlito, A. and Polidoro, F 146

Studies on Lymphoid Cells of Adenoid Tissue in Relation to Clinical Findings

Meistrup-Larsen, K.-L; Mogensen, H.H.; Helweg-Larsen, K.; Permin, H.; Andersen,

V.; Rygaard, J., and Sørensen, H 158

Stability of Myringoplasty Based on Late Results

Tos, M171

Book Reviews 182

Announcement 184 
No. 4

Original Paper

Motion Sickness and Space Sickness: Clinical and Experimental Findings

Megighian, D. and Martini, A185

Single-Response Variability of Air and Water Caloric Reactions

Nijhuis, B.G. and Huygen, P.L.M 196

Anisocoria in Inner Ear Lesions

Nakajima, S.; Moriuchi, H.; Baba, M.; Egami, T., and Kumagami, H

Serial Tympanometry and Middle Ear Status in 3-Year-Old Children

Fiellau-Nikolajsen, M 220

Laryngeal Cancer and Asbestos (with 1 colour plate)

Hillerdal, G. and Lindholm, C.-E 233

Immunoreactive Avian Pancreatic Polypeptide Occurs in Nerves of the Mammalian Nasal

Mucosa and Eustachian Tube

Uddman, R.;Håkanson, R., and Sundler, F 242

No. 5

Original Paper

Parotid Involvement by Lennert's Lymphoma

Ferlito, A. and Gale, N

Laryngeal Granuloma in the Early Stages of Wegener's Granulomatosis

Terent, A.; Wibell, L.; Lindholm, C.-E., and Wübrand,H 258

Hemidesmosome Morphogenesis in Laryngeal Carcinoma

Schenk, P 266

Influence of Seat Belt upon Maxillofacial Fractures

Afzelius, L.-E. and Rosen, C 277

Hillerdal/Lindholm

Plate I
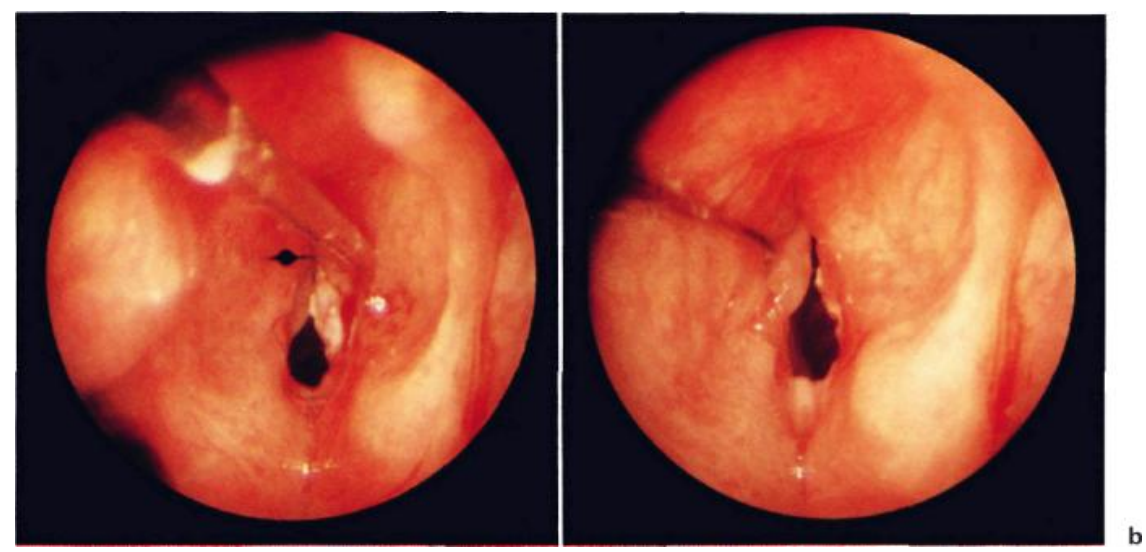

Fig. 1. Endoscopic photograph of the larynx, showing cancer in a 50-year-old man (case PB) with pleural plaques (fig. 2). a Black dot indicating the left ventricular fold. The right ventricular fold is held to the side by a suction tube, revealing the cancer of the right vocal cord classified as T3 (TNM Classification, Genoa 1978). b When the left ventricular fold is moved laterally, an oedematous left vocal cord is visible but has no cancer, according to multiple biopsies.

ORL, Vol. 42 
S. Karger, Basel
Contents IV

Study of a Simultaneous Lobe-Vertex and Membrane-Vertex Recording Technique in Auditory Brainstem Response

Okitsu, T.;Kusakari, J.;Ito, K., and Tomioka, S 282

Statistical Evaluation of Nystagmus in Cupulometry

Boumans, L.J.J.M.; Rodenburg, M., and Maas, A.J.J 292

Effects of C02 Inhalation on Cochlear Blood Circulation

Hultcrantz, E.; Larsen, H.C., and Angelborg, C 304

No. 6

Original Paper

Cholesteatoma. Etiology, Nosology and Tympanoplasty

Wullstein, H.L. and Wullstein, S.R 313

Surface Structures of Vestibular End Organs in Surgical Specimens

Ylikoski, J 336

Adenoid Cystic Carcinoma of the Head and Neck. Controllable and Uncontrollable Factors in

Treatment and Prognosis

Chilla, R.;Schroth, R.;Eysholdt, U., and Droese, M 346

Announcement $\quad 368$

Author Index 369

Subject Index 370

All rights reserved.

No part of this publication may be translated into other languages, reproduced or utilized in any form or by any means, electronic or mechanical, including photocopying, recording, microcopying, or by any information storage and retrieval system, without permission in writing from the publisher.

S. Karger AG, P.O. Box, CH-4009 Basel (Switzerland) Printed in Switzerland by Thür AG Offsetdruck, Pratteln 